\title{
Why Does Wealth Vary Among College Graduates?
}

\author{
Angelyque Campbell
}

I

'm pleased to take part in this discussion on a topic of great interest to the Board of Governors of the Federal Reserve System. It is also great to see fellow colleagues from the race and wealth convenings held at the Board over the past few years as well.

Throughout the period of financial unrest that we now refer to as the Great Recession, the Board endeavored to better understand the effects of the financial crisis and the significant erosion of housing wealth experienced by communities of color when house prices plummeted. ${ }^{1}$ After our inquiry, we extended an invitation to several experts who shared their perspectives about both the recession's impact on race and wealth trends and the short-term and longer-term recovery and wealth rebuilding efforts for affected communities of color. While experts discussed with the Board key drivers of the racial wealth gap-homeownership, intergenerational transfers, and labor - we did not fully explore the role of education in those conversations. So, I am grateful to my Federal Reserve colleagues Bill Emmons and Ray Boshara for conducting this research and holding this event to expand the discussion.

The Emmons and Ricketts article starts with a firmly held belief in our society that "more education is correlated with higher wealth." It follows that households whose members hold advanced degrees should have the earnings, savings, and investment potential to withstand personal or macro financial shocks. Yet, Emmons and Ricketts find in their research that this concept is not highly predictive of racial and ethnic wealth gaps. It is important to understand what they were trying to test. For me, not being of the economist persuasion, I must get past terms such as "postracial" and "luck" because my academic and professional experiences would suggest otherwise.

I do give the authors tremendous credit for structuring a research framework that attempts to answer the yet unsolvable puzzle of the definitive cause of the racial wealth gap. To a legal and policy professional as myself, I use research to help point me to viable policy solutions (or rule out solutions that may not work). In the Emmons and Ricketts article, I learn that

Angelyque Campbell is the manager of the policy analysis and communications units in the Division of Consumer and Community Affairs (DCCA) at the Board of Governors of the Federal Reserve System. The author extends special thanks to DCCA staff Alejandra Lopez-Fernandina, senior policy analyst; Jeff Larrimore, senior economist, for SHED data analysis; and Jazmin Harper, policy intern, for additional data support. This article was prepared for remarks delivered at the symposium, "Does College Level the Playing Field? Racial and Ethnic Differences in Family Wealth Among College-Educated Families," sponsored by the Center for Household Financial Stability and the Research Division of the Federal Reserve Bank of St. Louis, May 25-26, 2016.

Federal Reserve Bank of St. Louis Review, First Quarter 2017, 99(1), pp. 41-43. http://dx.doi.org/10.20955/r.2017.41-43

(c) 2017, Federal Reserve Bank of St. Louis. The views expressed in this article are those of the author(s) and do not necessarily reflect the views of the Federal Reserve System, the Board of Governors, or the regional Federal Reserve Banks. Articles may be reprinted, reproduced, published, distributed, displayed, and transmitted in their entirety if copyright notice, author name(s), and full citation are included. Abstracts, synopses, and other derivative works may be made only with prior written permission of the Federal Reserve Bank of St. Louis. 


\section{Campbell}

education is not the cure-all to the racial wealth gap that society has long heralded because the attainment of higher education did not protect the wealth of college-educated Blacks and Hispanics during the most recent recession.

It is at this point in the article that the authors delve into a discussion about financial decisionmaking, which I essentially describe as choices and behaviors. When discussing the racial wealth gap, experts tend to pursue two solution paths-structural or behavioral. If the goal is to eliminate the racial wealth gap completely, one must deal with structural issues such as ongoing discrimination or legacies of historical inequities that I contend have been codified in our nation's legal systems and public policies. These factors are what Emmons and Ricketts refer to as the "unobservable factors." If the goal is to improve the financial outcomes for certain historically disadvantaged groups, then some experts assert that addressing the groups' attitudes and decisions about their personal finances may be a more attainable goal.

Yet, solutions that involve personal decisions become precarious when the available choices are limited from the start. In recent research, the Board's third annual Report on the Economic Well-Being of U.S. Households ${ }^{2}$ highlights findings from the Survey of Household and Economic Decisionmaking (SHED). ${ }^{3}$ These survey findings provide valuable insights into the well-being of households and consumers.

Two sections of the economic well-being report, "Education and Human Capital" and "Education Debt and Student Loans," are particularly relevant to this discussion. The report captures what the SHED survey “....asks respondents about their educational experience, their perceptions of the value of their degree, and-among those who did not complete a college degree-why they did not continue their education. The survey also inquires about the financing of education and the use of student loans" (p. 47).

The model used by Emmons and Ricketts posits that education does not produce equal returns across demographic groups, which in turn suggests that education does not help explain the racial wealth gap. SHED results support this view. From the SHED survey, we see that the return on education may not be even across education sectors, which matters for the racial wealth gap since the likelihood of attending college, and the type of college attended, differs based on the background of one's parents. For example, for those whose parents did not attend college, 22 percent of respondents 25 to 34 years of age attended a private for-profit school compared with the 3 percent of respondents with at least one parent with a bachelor's degree. ${ }^{4}$ Further, SHED finds that among the respondents, students attending for-profit schools are more likely to be students of color or first-generation college students and are less likely to complete their degree. ${ }^{5}$ The SHED results also show a lower repayment performance among students who attended for-profit institutions, and these students were disproportionately Black and Hispanic. ${ }^{6}$

What these survey findings tell me is that "wealth begets wealth." If you attend the right school, enter the right professional field, have access to the right networks, exercise a diversified strategy in your investments, and have a safety net to fall back on in times of financial peril, then your advanced degree with the right set of conditions may lead to higher wealth returns. One's starting point does matter! If the unobservable factors listed above are also taken into consideration, then education, as the article suggests, may be worth leaving on the table as an 
explanatory variable of the racial wealth gap. As a matter of public policy, education-when it works well—can lead to a host of positive outcomes and intergenerational benefits. But when it fails, the setbacks tend to trigger a set of decisions that feel irreversible.

So, what is my final analysis? We need to keep talking across disciplines. Research models pared with a multidisciplinary context can yield greater understanding and fresh insights, and this research symposium offers us this opportunity.

\section{NOTES}

1 Kochhar, Rakesh; Fry, Richard and Taylor, Paul. "Wealth Gaps Rise to Record Highs Between Whites, Blacks and Hispanics." Washington, DC: Pew Research Center, July 2011. From 2005 to 2009, Hispanic households were hit the hardest among all races, losing half of their home equity: Median equity values fell from $\$ 99,983$ to $\$ 49,145$. Home equity values among Black families also declined but less sharply, falling from $\$ 76,910$ in 2005 to $\$ 59,000$ in 2009. Among White homeowners, values fell from $\$ 115,364$ to $\$ 95,000$.

2 Board of Governors of the Federal Reserve System. Report on Economic Well-Being of U.S. Households in 2015. Washington, DC: Board of Governors of the Federal Reserve System, May 2016.

3 Board of Governors of the Federal Reserve System. "Survey of Survey of Household Economics and Decisionmaking." May 25, 2016; https://www.federalreserve.gov/communitydev/shed.htm.

4 SHED, p. 47.

5 SHED, p. 56.

6 SHED, p. 56. 
